\title{
Profesor Adam Sławomir Gala
}

\section{(1944-2013)}

17 grudnia 2013 r. na łódzkim cmentarzu Doły odbył się pogrzeb profesora doktora habilitowanego Adama Sławomira Gali - dialektologa, onomasty, założyciela łódzkiej logopedii, związanego przez całe życie zawodowe z Wydziałem Filologicznym Uniwersytetu Łódzkiego.

Prof. zw. dr hab. Adam Sławomir Gala urodził się 9 czerwca 1944 r. w Piotrkowie Trybunalskim, gdzie także spędził lata szkolne. W rodzinnym mieście, po uzyskaniu w 1967 r. tytułu magistra filologii polskiej na Wydziale Filologicznym Uniwersytetu Łódzkiego, przez pięć lat pracował jako nauczyciel języka polskiego w I LO. Potem przeniósł się do Łodzi. W 1972 r. został zatrudniony w macierzystej uczelni i tam na Wydziale Filologicznym UŁ w 1976 r. uzyskał stopień doktora nauk humanistycznych w zakresie językoznawstwa. W 1985 r. na podstawie rozprawy Polskie nazwy

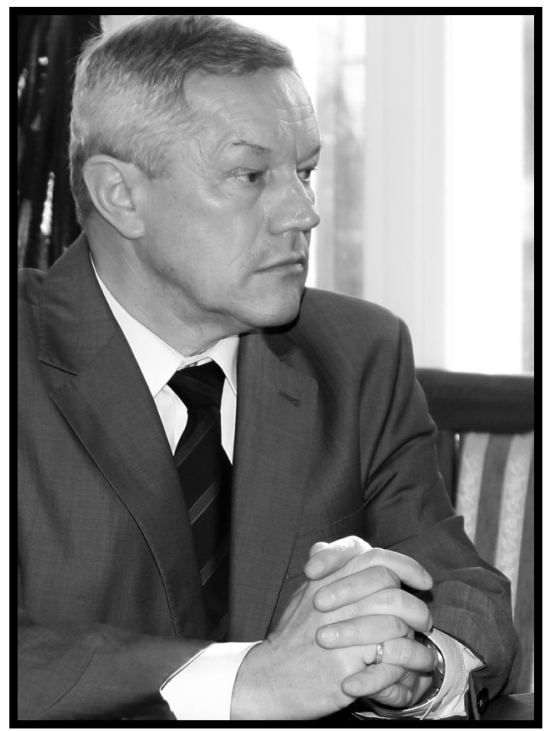

Profesor Adam Sławomir Gala (fot. Robert Kamiński, ze zbiorów Katedry Dialektologii Polskiej i Logopedii Uniwersytetu Łódzkiego)

This is an Open Access article distributed under the terms of the Creative Commons Attribution 3.0 PL License (creativecommons.org/licenses/by/3.0/pl/), which permits redistribution, commercial and non-commercial, provided that the article is properly cited. () The Author(s) 2014. 
osobowe z podstawowym -l-, -ł- w części sufiksalnej otrzymał tytuł doktora habilitowanego nauk humanistycznych w zakresie językoznawstwa na tym samym wydziale. Profesorem nadzwyczajnym UŁ został w 1989 r., profesorem nauk humanistycznych - w 1995 r., a w 1997 r. - profesorem zwyczajnym.

Pierwszym obszarem badawczym, który stał się przedmiotem zainteresowania prof. Gali, była antroponimia. Tym zagadnieniom poświęcił monografie: Słowotwórstwo nazwisk i przezwisk ludności byłego powiatu piotrkowskiego, [w:] Studia Językoznawcze, IV, Wrocław, 1979; Słownik nazwisk i przezwisk ludności ziemi piotrkowskiej, Łódź, 1987; Polskie nazwy osobowe z podstawowym -l-/-ł-w części sufiksalnej, (1. wyd.) Łódź, 1985, (2. wyd.) Łódź, 1992; Nazwiska historyczne piotrkowian [XVI do poł. XVIII w.], Łódź, 2001 (współautorstwo z Elżbietą Piotrowicz).

Prof. Sławomir Gala przez wiele lat współpracował ze swoim mistrzem, prof. Karolem Dejną, dzięki czemu znaczną część Jego dorobku stanowi tematyka dialektologiczna. Duże znaczenie dla wiedzy o gwarach polskich ma dwutomowa monografia Małopolsko-ślasko-wielkopolskie pogranicze językowe, t. 1-2, Łódź, 1994.

Szczególnie ważne stało się stworzenie atlasu gwarowego, syntetycznego opracowania z zakresu geografii lingwistycznej, uwzględniającego materiał starszy i najnowszy. Prof. Gala był współautorem tej publikacji, brał udział w pracach koncepcyjnych oraz w eksploracji terenowej. Z Jego udziałem powstał Atlas gwar polskich pod kierunkiem prof. Karola Dejny, t. 1 - Małopolska, Karol Dejna (1998), t. 2 - Mazowsze, Karol Dejna, Sławomir Gala, Alojzy Zdaniukiewicz, Feliks Czyżewski (2000), t. 3 - Śląsk, Karol Dejna Sławomir Gala (2001), t. 4 - Wielkopolska, Kaszuby, Karol Dejna (2002).

W ostatnich latach prof. Sławomir Gala zajmował się słowotwórstwem gwarowym. Jego teksty w tym zakresie dały nowe spojrzenie na mechanizmy słowotwórcze w lokalnych odmianach języka ogólnego. Wprowadzeniem do tej tematyki były: Słowotwórstwo gwarowe a słowotwórstwo polszczyzny ogólnej (2000), Założenia badań słowotwórstwa w gwarach Polski środkowej (2002), Autonomiczna czy suplementarna rola słowotwórstwa $w$ definiowaniu gwar (2005), Od słowotwórstwa w gwarach do słowotwórstwa gwarotwórczego (2008). Opracowanie Kwestionariusza do badań słowotwórstwa i słownictwa w gwarach pogranicza wielkopolsko-małopolsko-mazowiecko-śląskiego (2008) oraz Indeksu alfabetycznego i indeksu a tergo do „Stownictwa ludowego...” Karola Dejny (współautorstwo z Grażyną Frank-Rakowską i Beatą Galą-Milczarek) (2010) stało się wyznacznikiem nowej metody zbierania i analizy materiału gwarowego. 
Prof. Galę jako specjalistę w dziedzinie gwar i onomastyki znano nie tylko w środowisku językoznawczym. Dowód uznania dla Jego dorobku stanowiło zaproszenie do udziału w opracowaniu haseł o języku polskim w Wielkiej encyklopedii PWN, t. I-XXXI, Warszawa, 2001-2005.

Działalność naukowa nie była jedyną domeną aktywności zawodowej prof. Gali. Bardzo dbał on o kształcenie młodej kadry naukowej. Współorganizował studia doktoranckie na Wydziale Filologicznym UŁ, którymi kierował w latach 1993-2009. Wypromował ponad 100 magistrów i 12 doktorów. Poza tym był recenzentem kilku prac habilitacyjnych.

W łódzkim środowisku naukowym prof. Sławomir Gala dał się poznać jako dobry organizator, umiejący skutecznie zarządzać zespołem. Był prodziekanem Wydziału Filologicznego UŁ (1986-1989), kierownikiem Zakładu Dydaktyki Języka i Literatury Polskiej (1993-1997), a następnie kierował Katedrą Dialektologii Polskiej. Nie bał się trudnych wyzwań. Właściwie z niczego udało mu się stworzyć nowy kierunek - logopedię. To dzięki Jego inicjatywie od 2011 r. istnieje Katedra Dialektologii Polskiej i Logopedii na Wydziale Filologicznym UŁ.

Poza tym pełnił różne funkcje w gremiach i towarzystwach naukowych. Był członkiem Sekcji Językoznawstwa KBN (2002-2004) oraz członkiem Zespołu Ekspertów ds. Obsady Stanowisk Lektorów i Wykładowców Języka i Literatury Polskiej w Ośrodkach Zagranicznych przy MEN (1991-1998), a także zastępcą przewodniczącego zarządu Polskiego Towarzystwa Językoznawczego (2005-2006). Brał również udział w pracach Komisji Dialektologicznej Międzynarodowego Komitetu Slawistycznego oraz Komisji Dialektologicznej i Komisji Onomastycznej przy Komitecie Językoznawstwa PAN.

Przez wiele lat zasiadał w Radzie Oddziału PAN w Łodzi i w Prezydium Klubu Akademickiego. Jako członek zwyczajny Łódzkiego Towarzystwa Naukowego i przewodniczący Wydziału I ŁTN, a także przewodniczący Komisji Językoznawczej Oddziału PAN w Łodzi wykazywał się dużą aktywnością. Szczególnie swój wkład zaznaczył jako redaktor naczelny „Rozpraw Komisji Językowej Łódzkiego Towarzystwa Naukowego".

Prof. Gala kładł również nacisk na kontakty z innymi ośrodkami akademickimi i instytutami naukowymi. Najściślejsze związki łączyły go z Zakładem Filologii Ukraińskiej Instytutu Filologii Słowiańskiej UMCS. Ponadto współpracował z instytutami Narodowej Akademii Nauk Ukrainy (Lwów, Kijów), Uniwersytetem Tarasa Szewczenki w Kijowie, Uniwersytetem Łomonosowa w Moskwie, Uniwersytetem w Kazaniu, Uniwersytetem w Wołgogradzie 
i Syberyjskim Uniwersytetem w Krasnojarsku (m.in. jako promotor obronionej rozprawy doktorskiej dr. Eugeniusza Stupińskiego Polszczyzna okolic Krasnojarska).

Wielostronna aktywność i bogactwo dokonań przełożyły się na nagrody i odznaczenia. Za Atlas gwar polskich (tom Mazowsze), opracowywany wspólnie z prof. Karolem Dejną, został wyróżniony Dyplomem Honorowym Zarządu Miasta Stołecznego Warszawy, Towarzystwa Miłośników Historii w Warszawie, Muzeum Literatury im. Adama Mickiewicza, Towarzystwa Przyjaciół Warszawy, Archiwum Państwowego m.st. Warszawy, Muzeum Historycznego m.st. Warszawy, Biblioteki Publicznej m.st. Warszawy. Otrzymał również m.in. Złoty Krzyż Zasługi, Krzyż Kawalerski Orderu Odrodzenia Polski, Medal Komisji Edukacji Narodowej. W 2013 r. za szczególne zasługi dla UŁ został nagrodzony Medalem Universitas Lodziensis Merentibus.

Jako uczennica Profesora na zawsze zapamiętam Jego wielką rzetelność naukową oraz uczciwość wobec młodszych koleżanek i kolegów. Ilekroć korzystał z materiałów magistrantów czy doktorantów, skwapliwie odnotowywał to $\mathrm{w}$ swoich tekstach. Bardzo przestrzegał solidności pracy, gruntownego weryfikowania źródeł.

Podczas badań terenowych miałam okazję przekonać się o jego umiejętności słuchania i o tym, jakim szacunkiem darzy swoich rozmówców.

Był tytanem pracy i tego samego wymagał od najbliższego otoczenia. Rozumiał chwile słabości, nawet zwątpienia swoich uczennic, ale nie pozwalał na zwolnienie tempa, zrezygnowanie z tego, co się rozpoczęło. Jego życzliwość, wyrozumiałość, umiejętność łagodzenia sporów, dostrzegania w ludziach tego, co dobre, będzie dla mnie zawsze niedoścignionym wzorem.

Profesora cechowała jakże dziś rzadko spotkana cecha - wyjątkowa skromność, która momentami wydawała mi się przesadna. Potrafił pozostawać w cieniu swojego mistrza. Z niebywałą estymą odnosił się do prof. Karola Dejny nawet wtedy, gdy już sam był profesorem o znaczącym dorobku i mentorem dla swoich uczennic. Ta relacja mistrza i ucznia z biegiem lat przekształciła się w partnerstwo, jednak zawsze prof. Gala podkreślał, jak wiele zawdzięcza prof. Dejnie i nie zapominał o należnym dystansie. W ostatnich latach życia prof. Dejny opiekował się sędziwym nauczycielem troskliwiej niż niejeden rodzony syn.

Prof. Gala miał jeszcze tyle zamierzeń, propozycji współpracy, mówił o wielu pomysłach, które warte są zrealizowania. Zapał do działania i witalność przekazywał swoim współpracownicom z Katedry Dialektologii UŁ, które 
planowały zorganizowanie w 2014 r. jubileuszu z okazji Jego 70. urodzin. Niestety, uroczystość ta się nie odbyła...

\section{Dorota Krystyna Rembiszewska}

Keywords: obituary notice; Adam Sławomir Gala (1944-2013); Poland; dialectology; onomastics; linguistics; Polish studies

Słowa kluczowe: nekrolog; Adam Sławomir Gala (1944-2013); Polska; dialektologia; onomastyka; językoznawstwo; polonistyka 